\title{
Teaching in health residencies: knowledge of preceptors under Shulman's analysis
}

\author{
Ensino nas residências em saúde: conhecimento dos preceptores sob análise de Shulman \\ Enseñanza de la residencia de salud: conocimiento de preceptores bajo el análisis de Shulman
}

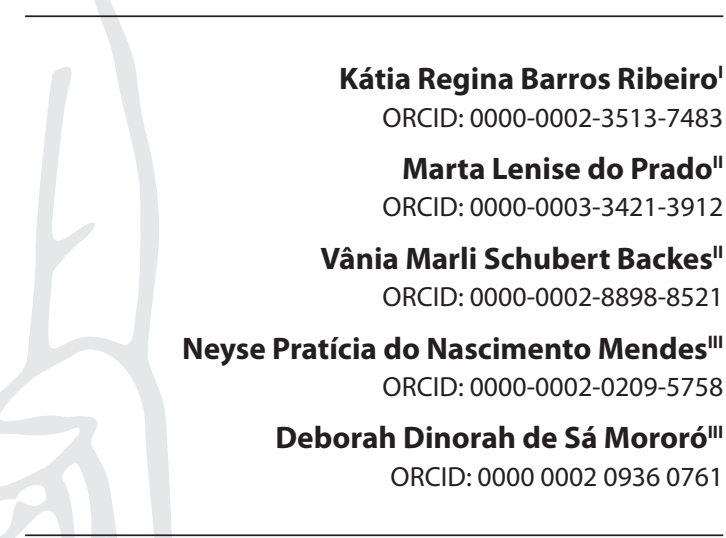

'Universidade Federal do Rio Grande do Norte. Natal, Rio Grande do Norte, Brazil.

"Universidade Federal de Santa Catarina. Florianópolis, Santa Catarina, Brazil.

I'Hospital Universitário Onofre Lopes. Natal, Rio Grande do Norte, Brazil.

How to cite this article: Ribeiro KRB, Prado ML, Backes VMS, Mendes NPN, Mororó DDS. Teaching in health residencies: knowledge of preceptors under Shulman's analysis. Rev Bras Enferm. 2020;73(4):e20180779 doi: http://dx.doi.org/10.1590/0034-7167-2018-0779

Corresponding author: Kátia Regina Barros Ribeiro E-mail:katia_rbr@yahoo.com.br

EDITOR IN CHIEF: Antonio José de Almeida Filho ASSOCIATE EDITOR: Mitzy Danski

Submission: 01-12-2019

Approval: 08-20-2019

\begin{abstract}
Objectives: to understand how the pedagogical knowledge that integrates the basic knowledge of teaching is perceived by preceptors in residents' teaching-learning process. Methods: a qualitative research conducted by semi-structured interview from December 2013 to July 2014, with 31 preceptors of residency programs of three university hospitals in northeastern Brazil. For analysis, the Grounded Theory's proposal was used and supported by Atlas ti 7.0 software. Results: preceptors integrate preceptorship with basic teaching knowledge proposed by Lee Shulman, with emphasis on General Pedagogical Knowledge when seeking strategies to better work on specific and disciplinary content, and Pedagogical Content Knowledge when adapting content to make it comprehensible to residents. Final Considerations: the study allowed us to understand how Shulman's basic knowledge of teaching is perceived by preceptors. It is recognized that they integrate knowledge into the preceptorship, highlighting the General and Pedagogical Content Knowledge.

Descriptors: Preceptorship; Health Education; Teaching; Knowledge; Education, Continuing
\end{abstract}

\section{RESUMO}

Objetivos: compreender como os saberes pedagógicos que integram o conhecimento base para o ensino são percebidos pelos preceptores no processo ensino-aprendizagem dos residentes. Métodos: pesquisa qualitativa, realizada por entrevista semiestruturada, de dezembro/2013 a julho de 2014, com 31 preceptores de programas de residência de três hospitais universitários do nordeste brasileiro. Para análise, utilizou-se a proposta da Teoria Fundamentada nos Dados, com apoio do software Atlas ti ${ }^{\circ}$ 7.0. Resultados: preceptores integram a preceptoria com conhecimentos base para o ensino propostos por Lee Shulman, com destaque ao Conhecimento Pedagógico Geral, quando buscam estratégias para melhor trabalhar conteúdos específicos e disciplinares, e o Conhecimento Pedagógico do Conteúdo, quando adequam o conteúdo para torná-lo compreensivo aos residentes. Considerações Finais: o estudo permitiu compreender como os conhecimentos base para o ensino, de Shulman, são percebidos pelos preceptores. Reconhece-se que eles integram conhecimentos à preceptoria, destacando-se os Conhecimentos Pedagógico Geral e do Conteúdo. Descritores: Preceptoria; Educação em Saúde; Ensino; Conhecimento; Educação Continuada.

\section{RESUMEN}

Objetivos: comprender cómo los preceptores perciben el conocimiento pedagógico que integra el conocimiento básico para la enseñanza en el proceso de enseñanza-aprendizaje de los residentes. Métodos: investigación cualitativa, realizada mediante entrevista semiestructurada, de diciembre/2013 a julio/2014, con 31 preceptores de programas de residencia de tres hospitales universitarios en el noreste de Brasil. Para el análisis, utilizamos la teoría propuesta basada en los datos, con el soporte del software Atlas ti ${ }^{\circ}$ 7.0. Resultados: los preceptores incluyen el conocimiento básico para la enseñanza propuesto por Lee Shulman, con énfasis en el Conocimiento Pedagógico General, cuando buscan estrategias para trabajar mejor en el contenido específico y disciplinario, y el Conocimiento Pedagógico del Contenido, cuando se ajustan al contenido para hacerlo los residentes. Consideraciones Finales: el estudio permitió comprender cómo los preceptores perciben los conocimientos básicos de la enseñanza de Shulman. Se reconoce que integran el conocimiento a la preceptoría enfatizando el Conocimiento Pedagógico General y del Contenido. Descriptores: Preceptoría; Educación en Salud; Enseñanza; Conocimiento; Educación Continua. 


\section{INTRODUCTION}

Residency programs began in Brazil in 1944, with the purpose of practical training of younger doctors by those with more experience. From 1976, other health professions adhered to this proposal and created the Multidisciplinary Health Residency in a Health Unit of Rio Grande do Sul State ${ }^{(1)}$.

Over the years, health residency programs have been expanding. Through struggles for improvements and legalization with the competent bodies, strategies of professional specialization, legally recognized as Lato Sensu Graduate, began to be considered. They were marked as in-service training and had the preceptor responsible for articulating theory with practice and providing the resident in training with service learning.

Preceptor is a professional who develops the teaching practice in the scope of his work, and in assuming this role of educator, needs to be aware of the responsibility that he has with training in the context in which he is inserted ${ }^{(2-3)}$. For this, it is necessary that this preceptor knows the objectives to be achieved, master knowledge on his practice and specialty, as well as have skills in the art of teaching.

In this context, when considering preceptorship as a health teaching practice, in which learning permeates the scope of work, it is believed that the professional inserted in care practice, in developing the role of preceptor also uses knowledge for teaching.

Lee Shulman ${ }^{(4-5)}$, professor of educational psychology and medical education at the University of Michigan, came to understand that doctors built much of their knowledge from their practices. Thinking in the field of teaching, he believes that many ideas arise from experience and argues that in the evolution of knowledge building, when asked to explain what is known, new understandings are built. In this movement, knowledge is transformed as to how to teach it, making it more understandable to others ${ }^{(6)}$.

Thus, knowledge for teaching is constructed from the movement of interaction and reflection with the learning setting and related knowledge. It is becoming increasingly clear that there are differences between'knowing content' and 'knowing how to teach content'. For learning to be concrete, it is not satisfying to know a subject in all its specificity, but to know strategies that allow talking about the subject in order to be fully understood.

In this context, Shulman ${ }^{(4-5)}$ talks about basic knowledge of teaching, composed of seven knowledge. In addition to subject knowledge and knowledge about students and their characteristics, Shulman points out pedagogical knowledge proper and/or related to the field of pedagogy as General Pedagogical Knowledge; curriculum knowledge; educational context knowledge; Pedagogical Content Knowledge, and Objective knowledge; educational purposes and values; philosophical and historical foundations $s^{(5)}$. For the development of this knowledge, there are four main sources ${ }^{(5)}$ : academic background in the subject to be taught (requires literature knowledge and scientific content, in addition, associates the historicalphilosophical knowledge about the nature of knowledge in the fields of study); the materials and context of the institutionalized education process (lists curriculum, textbooks, school structure and funding, as well as professor career organization); research on education, development and social disposition of learning, among other phenomena that integrate and interact with the educational practice; knowledge that comes from practice ${ }^{(5)}$.
In this area, it is noteworthy that Lee Shulman's theoretical framework is particularly recognized by the theory of Pedagogical Content Knowledge (PCK) ${ }^{(6)}$. PCK is defined as the amalgam between subject content and pedagogical knowledge, and constitutes the professor's understanding and interpretation of what should be taught and how it should be taught ${ }^{(4-5)}$. This knowledge requires the professor to broaden his view and understand how the complexity of their knowledge can be have a new meaning in a way that can be better understood by the student ${ }^{(6)}$.

To turn content into teachable subject matter, Shulman ${ }^{(4-5)}$ states that there are naturally occurring steps in PCK building. It all starts from the reflection on a general knowledge for content organization and structuring, in which the professor selects the materials to be used, examples, illustrations and explanations to be presented. This is when they adapt the content to the students' characteristics, context and experience. This is followed by the instructional phase, and in this phase the professor reflects his actions, assesses the student's comprehension during his act and begins to reflect on his performance. The professor restructures his knowledge, reconstructs his understandings and recreates his attitude towards teaching-learning ${ }^{(4-5)}$.

This process is called Model of Pedagogical Reasoning and Action, which is composed of 6 steps, defined as: (a) understanding; (b) transformation, defined by the stages of preparation, representation, selection and adaptation; (c) teaching; (d) assessment; (e) reflection; and (f) new understanding ${ }^{(5)}$.

Although Shulman discusses professor education and considering that the professor is the one who is in a teaching/learning situation, whether formal or not, he advocates the idea that the health professional inserted in the field of work by becoming a preceptor in a medical or multiprofessional residency program, in addition to your responsibility for care, you also assume the role of educator. For this, the professor needs to develop in himself a repertoire of knowledge for the exercise of the educational practice.

Thus, the intention to investigate this theme lies in offering subsidies for a preceptor's knowledge repertoire in the teaching of clinical practice, based on Lee Shulman's theoretical framework that deals with the basic knowledge of teaching. This study has its relevance as it invites to strengthen the movement of appreciation and recognition of the preceptor's identity and the necessary knowledge to practice preceptorship, as well as constitutes theoretical support to the planning of a pedagogical training model. In this model, the preceptor will be able to develop the necessary skills to teach professional qualification for SUS (Sistema Único de Saúde - Brazilian Unified Health System), so that the speech becomes the action of a successful work.

\section{OBJECTIVES}

To understand how the pedagogical knowledge that integrates the basic knowledge of teaching is perceived by preceptors in residents' teaching-learning process.

\section{METHODS}

\section{Ethical aspects}

According to Resolution 466 of December 12, 2012 of the Brazilian National Health Board (Conselho Nacional de Saúde), 
the study was approved by the Research Ethics Committee of Universidade Federal de Santa Catarina, and followed all recommendations. Participants signed the Free and Informed Consent Term (FICT), which was filed by the researcher responsible to ensure anonymity were identified with the name of stars.

\section{Theoretical-methodological framework}

It was used as Lee Shulman's theoretical framework that deals with the basic knowledge of teaching. As a methodological framework, it was based on the coding technique proposed by the Grounded Theory, based on Straus and Corbin ${ }^{(7)}$. This theory refers to the conceptual organization of raw data into categories, constituting three distinct and complementary stages called: a) open coding; b) axial coding; and c) selective coding. For this study, there were only two initial steps: a) open coding and b) axial coding, to finally reach the analysis categories. The selective coding step was not fulfilled, as this procedure has as its purpose theory building, which does not correspond to the study objectives.

\section{Type of study}

This is a qualitative and exploratory-descriptive research.

\section{Methodological procedures}

To carry out the study, following institution consent, coordinators and tutors of multidisciplinary and medical residency programs were contacted. This contact was made to indicate preceptors that could contribute to the research, taking into account their insertion and participation in the program, configuring an intentional selection procedure. Each preceptor indicated was approached and by agreeing to participate in the study was submitted to an interview. To delimit the sample, statement saturation was considered. In this process, privacy of participants was respected as it was decided to collect in a closed and comfortable environment, to ensure information confidentiality.

\section{Study setting}

This research was conducted in three university hospitals (HUs) in a city in northeastern Brazil, which are part of the Brazilian Company of Hospital Services (EBSERH - Empresa Brasileira de Serviços Hospitalares), two of which are small and one medium. It is noteworthy that all make up the Health Care Network (medium and high complexity).

\section{Data source}

Thirty-one health professionals who played the role of preceptors in medical or multidisciplinary residency programs participated in this study. Those with more than 1 year of experience in preceptorship and who followed the activities of first and/or second year residents were included. Those preceptors who also had some employment as a professor in institutions of higher education or technical level were excluded, as well as those who coordinated or had already coordinated a residency program.

\section{Collection and organization of data}

Data collection was performed within 7 months, between December 2013 and July 2014. We used the semi-structured interview technique, under the guidance of a previously established script. To better capture the lines, the digital recorder was used. To ensure privacy, the interviews were conducted in a place previously agreed with the interviewees. Each interview lasted between 30 and 40 minutes.

After each interview, she was immediately transferred to her computer via Windows Media Player ${ }^{\oplus}$, as audio technology that lets you pause, rewind, and fast-track voice recording. The interview was transcribed to a text document in Microsoft Word ${ }^{\circledR}$, ensuring the reliability of the subjects' speech transcription.

\section{Data analysis}

Through the Atlas $\mathrm{ti}^{\circ} 7$ software interface, coding was performed, in which 162 codes initially emerged, in the step called open coding. Research questions and aspects that were directly related to the phenomenon under study were resumed. Rereading was continued, in which the similar codes were reorganized without altering or losing any fragment of the lines, totaling at the end 121 codes.

In the second stage, the related codes were grouped, characterizing the axial coding procedure ${ }^{(7)}$. At this point, the intention was to gather the data and establish connections between the $\operatorname{codes}^{(8)}$. At the end of these two stages, it was possible to visualize, in general, what the data presented about the phenomenon under study, composing the categories: (1) General Pedagogical Knowledge; (2) curriculum knowledge, educational context, educational goals and purposes, and other knowledge; (3) Pedagogical Content Knowledge.

\section{RESULTS}

Empirical material analysis revealed that preceptors use pedagogical knowledge proper and/or related to the field of pedagogy. These preceptors teach and realize that they correspond to knowledge that Shulman ${ }^{(6)}$ points out as basic knowledge of the professor's teaching, which will be described below.

\section{General Pedagogical Knowledge}

General Pedagogical Knowledge is that which concerns the planning and conduct of teaching and learning. This knowledge is intrinsically related to the professor's knowledge about the pedagogical practice he uses to teach, besides his affinity with the teaching-learning methodologies(5-6,9-11).

This category presents pedagogical knowledge as a knowledge revealed by preceptors, necessary for preceptorship. Many mentioned in their speeches the importance of having didactic knowledge, knowing how to do and what strategies to use to perform preceptorship, as observed in the following statements:

Didacticism, the training part, so there can be a way to share this knowledge with them. (YED) 
He provides care by habit, but to understand the subject that is approached he brings this theoretical basis, but there at the moment there will be situations that he's never seen before and that way to share knowledge, I think this training should be there, this didactic side of the professional to send this message. (PRÓCION)

Often this pedagogical knowledge is attributed as teaching knowledge. The preceptor, in mediating the resident's learning in practice, feels the need to know how to teach and associates him with the knowledge of being a professor, teaching knowledge, as illustrated in the statements excerpts.

I think [it's necessary to have] knowledge of what teaching is really like. (REGULUS)

Besides professional training, I think it's good to have previous teaching experience, so you can have more ease, so you know the best way to teach. (BELLATRIX)

[It's necessary to have] some expertise on teaching matters. (EPSILON)

The person who's involved mainly with graduate teaching, he may be a preceptor who's a professor or a preceptor who's not a professor, who's only a technician, but it is interesting that this person has some teaching knowledge, some teaching training. (PROPUS)

It was pointed out that without pedagogical knowledge, performing preceptorship becomes a difficult task. Reports show that preceptors feel they cannot meet residents' expectations and sometimes end up on instinctual preceptorship:

There is a didactic for that [...] There is a basic rule to be a preceptor, that is to say, you have to go through academic matters, in the sense of having a specialization, of having a master's degree with this methodological bond, of showing didactics rather than just broaching a subject, there is a way to teach things which is what makes it harder, in a general scope of administrative technicians. (PRÓCION)

We don't have any kind of training or pedagogical technique, we do it more instinctively than anything, each one has his way to teach. (POLAR)

You don't know, you have no preparation, so we go and study by making do. (ANTARES)

It seems contradictory to think that preceptorship, despite being an activity of great responsibility, can be reduced by pure practice and passing on knowledge. Each preceptor performs the precept according to his or her practice and teaching knowledge that they bring with them, who have heard but not mastered. About this, Polar states how important pedagogical knowledge is for the development of better preceptorship:

I think that what could help a lot and improve preceptory would be pedagogical training [...] I'm a layman when it comes to pedagogy, but I'm not a person who has no knowledge either, I know that there is a pedagogical technique, I know there are specific ways to train certain subjects and that if they were taught to us, we could share [our knowledge] with them in a much better way. (POLAR)
Some preceptors pointed to the need for a pedagogical qualification or training, as well as the interest in learning how to teach. They pointed out that Stricto Sensu Graduate provides learning opportunities in this area and has repercussions on the preceptor's posture and practice. The preceptor becomes knowledgeable about methodological teaching strategies and, as a result, they feel more confident in leading the resident in their learning process.

There are colleagues who, in other times, would fully refuse to contribute, but because they are living this graduate thing, the colleagues are contaminated by this good thing. (ARCTURUS)

When you take a master's and doctorate's degree [...] there is a teaching to understand research and, in this teaching, there is also the lesson on expressing yourself and sharing knowledge [...] and you end up more apt to be a professor [...] (UNUK)

Since I'm taking a master's degree and we take many subjects related to this, that is to say, this teaching-learning process, like new ways of taking a stance when facing this new context that we live in, so the student is not only a knowledge absorber, rather [he is] always building that knowledge with you, so, I changed a bit the way I see things in this aspect to. (MAIA)

General Pedagogical Knowledge is recognized as necessary for the development of preceptorship. With this knowledge the preceptor can articulate theory and practice with propriety, conduct reflective practice and provide the resident with better quality training. In this sense, it is also important to highlight the contribution of professional qualification (Lato and/or Stricto Sensu) that can provide subsidies to the preceptor for a greater understanding about educational practices and bring pedagogical foundations for teaching at work.

\section{Curriculum Knowledge, Objectives, Purposes, and Values of the Residency Program, Educational Context and Other Knowledge}

In addition to General Pedagogical Knowledge, preceptors also highlighted other knowledge that is important for preceptorship and that make up the Knowledge Base of Teaching. These are related to residency program curriculum knowledge. According to Shulman ${ }^{(6)}$, this knowledge corresponds to the mastery of the objectives, goals and missions that guide the teaching program. Knowledge reveals the conscience and intentionality of the professor in his educational practice ${ }^{(6)}$.

[It's necessary to know] information on the subject organization chart, on how it effectively works. (YED)

They pointed to the need to know the purpose for which residents are graduating, knowledge that integrates educational goals knowledge, purposes and values, and their philosophical and historical foundations, proposed by Shulman. Shulman ${ }^{(5-6)}$ points out that the professor becomes aware of the specific and general aspects that are linked to experiences, values, historical, and philosophical contexts, which guides him in teaching-learning.

It is also necessary to understand a little or a lot about internship, how it happens, what it aims at, how it is structured [...] how does 
our work come about? How do we work, how does our sector act so those activities are actually carried out and quality standards are reached? (HADAR)

I think you need to know what is the objective of internship [...] what is it I want to achieve with this internship, how do I want to train these professionals, what kind of professional I want to send into the workforce, what critical awareness those professionals will have so they are not mere task accomplishers. (MIRA)

Preceptors also highlighted the importance of knowing the educational context and the reality of the service in which they are performing. They correspond to knowledge about where education occurs, its physical structure and material resources, as well as the human resources involved, besides the social, economic and cultural context are related to this process and the political strategies that permeate this setting ${ }^{(5-6,9-11)}$. This is observed in the following statements:

To know how the whole hospital works, there must be a general notion of what's going on regarding SUS [Brazilian public health care system], of how even academia works now. (CANOPUS)

Living the experience of being a preceptor made him realize that other knowledge is needed to improve his practice of preceptorship, which also gives him greater security in mediation of teaching in service, as depicted in HADAR's testimony:

It was a rather new experience and we entered the interns' daily routines gradually [...] today, we have way more spontaneity and more safety to be [a preceptor], because I also know I have to demand a bit more from them. (HADAR)

In addition to this knowledge, some preceptors pointed out that they need to master other knowledge that permeates the field of senses, perception, sensitivity to human relationships that are established and lived throughout training. They emphasize that respect among professionals, knowing how to deal with people and establishing a good relationship with the resident, as well as with the patient and family member, are important factors for the development of preceptorship, highlighted in the following statements:

To know a little about what each one of us can give and what each one of us can take from a human point of view, what is necessary to have good relationships. (HADAR)

To be sensitive enough to remember that person is learning. (MAIA)

So, I think that knowing how to deal with others, teamwork, also understanding and highlighting and respecting the nuances of each professional, I think that is also very important. (LACAILLE)

I think there must be a good relationship between preceptor and intern. (DUBHE)

\section{Pedagogical Content Knowledge}

Preceptors know their practice and master knowledge (theoretical and practical) that residents do not know and/or have never experienced. It is from this moment that teaching begins and, in order for it to happen to provide learning, they need to understand what has to be learned and how to teach. This knowledge, PCK, is called by Shulman ${ }^{(5)}$, differing preceptor from resident.

We have this thing about knowing how to do it, but there is a way to do it that is as right as the one in the textbook but the student doesn't know about it. (ARCTURUS)

It is exactly what differentiates you from the student, let's call who's on the other side this way; it's understanding your message, not only providing care. (PRÓCION)

In this category, speeches that characterize PCK in preceptorship practice stand out. It is observed that preceptors believe that attitude is necessary to be able to teach and in some situations modify their posture and adapt their practice to teaching, as observed in the following statements:

[It was necessary that] / changed myself in the sense of knowing how to present myself, to stand without any shyness. (HADAR)

We try to teach our knowledge the best way possible [...] trying to act within the best practices. (BELLATRIX)

Creating new routines to train new people. (POLLUX)

Likewise, preceptors pointed out that it is not enough to know the content, the matter, but it is necessary to know how to teach, as can be observed in the following statements:

I design a strategy that simplifies it [...] so I kind-of organize it mentally and teach it. (UNUK)

There's a difference between knowing something and knowing how to teach it. It's not for everyone [...] just knowing it means nothing if [the person] doesn't know how to share knowledge. (PRÓCION)

You need to plan things and that everyone understands you. (MIRA)

Preceptors also attributed PCK to the gift of teaching, as illustrated in the following statements:

I think that teaching goes through, more or less, the gift of your liking to teach and of having "it" to teach, because sometimes you may even want to be a professor, study everything right to be a professor, all the techniques, all the courses, everything, and you may not perform well. But if you have that gift, that will, and you perfect yourself, then you will use both things together. (PROPUS)

Not everybody has this, I'll call it a talent or gift, of you sharing something and getting your message across. (PRÓCION)

Not everybody has the talent or the gift to be there and share knowledge. Sometimes the person is very technically skilled, perfect even [...] but he doesn't have the gift, [...] he knows that for himself, but to teach it, to share it with another person, sometimes it's not the deal, things don't work out. (MAIA)

This ability to teach the subject is pointed by preceptors as a difficult task and permeated with challenges that emerge daily 
in the work. About this, Polar points out that knowing how to articulate practice and theory is one of the most difficult challenges:

Teaching what is in the textbook is very easy, but teaching the way the student, the intern can notice the subtlety of what a patient speaks and transform it into what he is reading in the book, that is very hard. (POLAR)

\section{DISCUSSION}

A professor needs to master knowledge about the content to be taught, the structure of his discipline, his principles and other knowledge that will help him answer questions in each area that makes up teaching ${ }^{(12)}$. Professors need to understand curriculum structure and organization, the objectives, principles and educational values, as well as the context that guides this practice.

As much as the preceptor does not perform the teaching function, he fulfills the teaching of the practice in the context of residency programs in health, so we consider him an educator in practice. We aim to understand the knowledge that the preceptor uses to teach.

In this overview, it is noted that preceptors integrate to preceptorship some knowledge that guide them to this educational practice development. This knowledge corresponds to General Pedagogical Knowledge; curriculum knowledge; educational context knowledge; Pedagogical Content Knowledge, and Objective knowledge; educational purposes and values; philosophical and historical foundations, knowledge that Shulman points out as pedagogical knowledge proper and necessary to preceptorship.

Among the identified knowledge, General Pedagogical Knowledge, cited by most of study participants as essential to perform preceptorship, deserves attention. This knowledge corresponds to that in which educational conceptions and principles are manifested, and pedagogical strategies are applied. Teaching and learning situations are planned, organized and managed in order to overcome the simple mastery of content knowledge, seeking to achieve broader goals for education and training ${ }^{(11)}$. With this knowledge, preceptors work to teach in practice the strategies used for the content to be taught.

Preceptors believe that this knowledge, revealed as knowledge of being a professor, is the differential in conducting learning of residents. Mastering this knowledge requires specific training and its disability may imply failure to achieve program objectives. In this context, it is important to understand that the professional who develops preceptorship activities is directly related to the education field. However, many put themselves in the position of being present or existing only, being only a comprehensive part of the educational action ${ }^{(13)}$.

Perhaps such a stance may be due to the preceptor's lack of preparation for this activity, which may lead him to do it intuitively, based on the here and now. Without proper pedagogical knowledge, the preceptor may act on instinct according to what he has previously experienced or believes to be correct. Preceptorship is reduced to an empirical activity, characterized by routine transfer, care activities, tasks to be performed, where difficulties are found in working the investigative, critical and reflective attitude in the professional in training.
Preceptors dominate their profession knowledge, but do not dominate pedagogical knowledge, which is important in the performance of training/education. Thus, they end up acting intuitively, repeating models they experienced when they were students and referring to information transmission as teaching ${ }^{(13)}$.

They need to be aware that they are in a teaching and learning context and their new experiences will provoke situations that could restructure their knowledge, as well as extend it to other knowledge that will be their basis for teaching ${ }^{(11)}$.

In this process, preceptors feel the need to seek pedagogical qualification and point out that qualification through the Stricto Sensu Graduate provides them with knowledge about teaching and research. This assists in performing preceptorship and sometimes changes their posture and understanding of their role in the resident's training. It is in teaching that the professor realizes the need for pedagogical training and faces scarce possibilities and opportunities $^{(14-15)}$.

It must be understood that teaching a subject is essential to the definition of professor/preceptor quality criteria ${ }^{(16-17)}$. For this, besides content knowledge and pedagogical knowledge, the preceptor needs to be able to articulate this knowledge to curriculum knowledge, program content of which it is part, goals and objectives of education ${ }^{(17)}$. This will provide the preceptor with teaching skills. This knowledge was identified throughout the study, but with less prominence, as the need for this knowledge emerged throughout preceptorship.

Knowledge for preceptorship teaching also involves the moral and ethical understanding that drives and directs good service practice and citizenship, as well as sensitivity and a good relationship between preceptor and resident, expressed in the results. It is prized for a practice based on personal and social responsibility, in which theoretical knowledge, skills and attitudes constitute an ethical and moral matrix ${ }^{(18)}$. In addition, it is essential for the educator to cultivate a relationship based on respect, solidarity and lovingness towards the student, since he has the commitment and responsibility with his training ${ }^{(19)}$.

This knowledge was the basis of the preceptor during the educational process, as they felt the need to know more about these aspects that compose preceptorship, from the experiences and knowledge learned along his trajectory. Experience is one of the professor's sources of knowledge, as well as academic (technical-professional) training, educational materials and context, and research ${ }^{(20)}$.

However, knowing the content or having practical skills is not enough. The preceptor's domain knowledge needs not to restrict him to purely technical teaching, but to direct him to the comprehension of the whole and the complexity that is intrinsically related to PCK in teaching-learning.

This movement of articulation and integration between sources and basic knowledge of teaching, we call the Model of Reasoning and Pedagogical Action, which builds the expertise of the professor along his path ${ }^{(20)}$. This model, proposed by Shulman ${ }^{(12)}$, corresponds to a process composed of six elements (comprehension, transformation, instruction, assessment, reflection, and new comprehension) arranged in different stages that will help in PCK building ${ }^{(11)}$.

Aware or not professors rebuild, adapt and simplify the content to be taught ${ }^{(21)}$. However, it is from this movement in the Model 
of Pedagogical Reasoning and Action, proposed by Shulman, that the professor becomes more aware of the process and transforms content in such a way that makes it teachable and understandable to students.

Beyond simply passing on knowledge or performing tasks, the preceptor needs to understand his reality, the resident's world, the goals of his educational practice, the tools he can use in preceptorship. It is not enough to know the content, to know the institutional context, it is necessary to know how to teach. This knowledge is called by Shulman ${ }^{(5)}$ as PCK.

This knowledge was identified in the speeches of preceptors, related to their posture and attitude in the educational process. Thus, the resident is directed to understanding the practice and learning. However, how does this happen in everyday life? Given the speeches, this knowledge is the result of a reflective practice, in which the preceptor constitutes his educational process content knowledge in care practice.

For Shulman, PCK is a kind of amalgam between content and didactics, in which the professor develops knowledge of how to teach his specific subject, that is, knowledge for teaching ${ }^{(21-23)}$. It enables the professor to be resourceful in teaching practice, so that it helps lead students to learning in a participatory, reflective, creative way, using context-adapted teaching strategies ${ }^{(6,24-27)}$.

To this knowledge, some preceptors called it a gift to teach. This word, according to the Portuguese language dictionary, means "Gift, present; Worthiness, merit; Natural endowment; talent, gift, aptitude, college, ability, special ability to"(28). A gift is not learned, it is innate. Knowing how to teach is a knowledge that is learned, although some are easier than others. Knowing how to teach is modeled along the professor's path through his life story and socialization ${ }^{(24-27)}$.

Finally, when looking at preceptorship as a teaching activity, and the preceptor, the professional responsible for its performance, there is a need for didactic buildings that constitute the preceptor's knowledge repertoire and allow him to lead the resident to learning and a good practice in health care in SUS.

\section{Study limitations}

Understanding this phenomenon was not an easy task, as there were some limitations, such as the difficulty in the availability of preceptors to participate in the study due to the overload of daily activities. In addition, the Knowledge Base of Teaching theoretical framework, in preceptorship, was not a subject easily understood by the interviewees, perhaps because it is not part of their training.

\section{Contribution to nursing and health}

As contributions, it is believed that this study invites the scientific community to strengthen the movement of appreciation and recognition of the preceptor's identity and the necessary knowledge to practice preceptorship in health courses. It also constitutes theoretical support for the planning of a pedagogical training model, in which the preceptor can develop the necessary competences to the teaching of the practice in training and professional qualification for SUS. Thus, we can move from speech to the action of a successful work.

\section{FINAL CONSIDERATIONS}

The study allowed us to understand how the pedagogical knowledge that integrates the basic knowledge of teaching, based on Lee Shulman, is perceived by preceptors in residents' teaching-learning. In this sense, it is recognized that preceptors integrate knowledge into their practice of preceptorship, with emphasis on General Pedagogical Knowledge and PCK.

Knowledge about curriculum, as well as knowledge about the educational context, goals, purposes and educational values, and their philosophical and historical foundations are also present, although they are incorporated into preceptorship along its trajectory.

It is imperative the need for pedagogical knowledge, so that there is greater security and mastery of teaching-learning strategies, with pedagogical purpose and intentionality. Those who are in some ways approaching the academic realm, especially through Stricto Sensu Graduate courses, feel more confident in fulfilling their role as preceptor.

PCK, in turn, emerges in the speeches of study participants. This knowledge reflects knowledge transformation that the preceptor has and uses to be understood by residents. It is about knowing how to teach the practice, how to adapt knowledge so that the resident understands and learns. Often unconsciously, preceptors develop the Model of Pedagogical Reasoning and Action, building and reconstructing their knowledge about health practice.

It is necessary pedagogical preparation that guides preceptors to what they should know and to do, and what knowledge they need to master to anchor their practice, since the qualification directly affects the quality of their teaching.

Finally, much remains to be discovered about this phenomenon. Further studies need to be carried out in order to broaden knowledge on this subject. It is also necessary for preceptors to be aware of the knowledge necessary for preceptorship teaching, so that they constitute the movement of building their knowledge repertoire for better performance in teaching health practice.

\section{FUNDING}

This work was carried out with the support of the Higher Education Personnel Improvement Coordination - Brazil (CAPES) - Financing Code 001

\section{REFERENCES}

1. Silva LB. Residência Multiprofissional em Saúde no Brasil: alguns aspectos da trajetória histórica. Rev Katál [Internet]. 2018 [cited 2018 Aug 12];21(1):200-9. Available from: https://doi.org/10.1590/1982-02592018v21n1p200

2. Ribeiro KRB, Prado ML. A prática educativa dos preceptores nas residências em saúde: um estudo de reflexão. Rev Gaúcha Enferm [Internet] 2014[cited 2015 May 26];35(1):161-5. Available from: http://seer.ufrgs.br/RevistaGauchadeEnfermagem/article/view/43731/28959 
3. Vendruscolo C, Trindade LL, Prado ML, Kleba ME. Rethinking the Health Care Model through the reorientation of training. Rev Bras Enferm[Internet]. 2018 [cited 2018 Aug 20];71(Suppl 4):1580-8. Available from: http://dx.doi.org/10.1590/0034-7167-2017-0055

4. Shulman L. Those who understand: knowledge growth in teaching. educational researcher [Internet]. 1986[cited 2015 May 26];15(2):4-14. Available from: http://www.fisica.uniud.it/urdf/masterdidsciud/materiali/pdf/shulman_1986.pdf

5. Shulman L. Conocimientos y enseñanza: fundamentos de la nueva reforma. Profesorado [Internet]. 2005 [cited 2015 May 26];9(2):1-30. Available from: http://www.ugr.es/ recfpro/rev92art1.pdf

6. Ingui D. Entrevista Lee Shulman. Rev Eletrôn Jornalismo Científ [Internet]. 2010[cited 2015 May 26]. Available from: http://www.comciencia. $\mathrm{br} /$ comciencia/?section $=8 \&$ tipo $=$ entrevista\&edicao $=53$

7. Strauss AL, Corbin J. Pesquisa qualitativa: técnicas e procedimentos para o desenvolvimento. 2. ed. São Paulo: Artmed; 2008.

8. Santos JLG, Cunha K, Adamy EK, Backes MTS, Leite JL, Sousa FGM. Data analysis: comparison between the different methodological perspectives of the Grounded Theory. Rev Esc Enferm USP. 2018;52:01-08. doi: 10.1590/S1980-220X2017021803303

9. Garcia CM. Como conocen los profesores la materia que enseñan: algunas contribuciones de la investigacion sobre conocimiento didactico del contenido. Profesorado [Internet]. 1992 [cited 2015 May 26];6(10):1-35.1992. Available from: http://www.inet.edu.ar/programas/ formacion_docente/biblioteca/formacion_docente/marcelo_garcia_como_conocen_docentes.pdf

10. Grossman PL. Un estudio comparado: las fuentes del conocimiento didáctico del contenido en la enseñanza del ingles en secundaria. Profesorado: revista de currículum y formación del profesorado [Internet]. 2005 [cited 2013 Jan 15];9(2):1-18. Available from: www.ugr.es/ recfpro/?p=235

11. Marcon D, Graça ABS, Nascimento JV. Reinterpretação da estrutura teórico-conceitual do conhecimento pedagógico do conteúdo. Rev Bras Educ Fís Esporte [Internet]. 2011[cited 2013 Jan 15];25(2):323-39. Available from: http://www.scielo.br/pdf/rbefe/v25n2/13.pdf

12. Shulman L. Knowledge and teaching: foundations of the new reform. Harvard Educ Rev[Internet]. 1987 [cited 2015 May 26];57(1):1-22. Available from: http://hepgjournals.org/doi/abs/10.17763/haer.57.1.j463w79r56455411

13. Meneses LBA, Leite VS, Pereira AJ, et al. Vivendo a formação de preceptores e tutores: uma experiência refletida. In: Ceccim RB, Meneses LBA, Soares VL, et al. Formação de Formadores para Residências em Saúde. Série Vivências em Educação na Saúde[Internet]. Porto Alegre: Rede Unida; 2018[cited 2015 May 26]. p. 61-74. Available from: http://historico.redeunida.org.br/editora/biblioteca-digital/serie-vivencias-em-educacao-na-saude/ formacao-de-formadores-para-residencias-em-saude-corpo-docente-assistencial-em-experiencia-viva-pdf

14. Nóbrega FS, Rocha RCS, Fernandes MCV. O curso de formação para preceptores sob o olhar do preceptor: resistência e desafios. In: Ceccim RB, Meneses LBA, Soares VL, et al. Formação de Formadores para Residências em Saúde. Série Vivências em Educação na Saúde [Internet]. Porto Alegre: Rede Unida; 2018[cited 2015 May 26]. p. 113-23. Available from: http://historico.redeunida.org.br/editora/biblioteca-digital/ serie-vivencias-em-educacao-na-saude/formacao-de-formadores-para-residencias-em-saude-corpo-docente-assistencial-em-experiencia-viva-pdf

15. Ceccim RB, Meneses LBA, Meneses J R, Alvarenga JPO. Preceptoria e tutoria: ação docente nas residências em saúde. In: Ceccim RB, Meneses LBA, Soares VL, et al. Formação de Formadores para Residências em Saúde. Série Vivências em Educação na Saúde [Internet]. Porto Alegre: Rede Unida; 2018[cited 2015 May 26]. p. 113-23.

Available from: http://historico.redeunida.org.br/editora/biblioteca-digital/serie-vivencias-em-educacao-na-saude/ formacao-de-formadores-para-residencias-em-saude-corpo-docente-assistencial-em-experiencia-viva-pdf

16. Madeira MZA, Lima MGSB. O significado da prática docente na constituição do saber ensinar das professoras do curso de enfermagem da Universidade Federal do Piauí. Texto Contexto Enferm [Internet]. 2010[cited 2015 May 26];19(1):70-7. Available from: https://www.scielo.br/ pdf/tce/v19n1/v19n1a08.pdf

17. Shuman L. Paradigmas y programas de investigación en el estudio de la enseñanza: una perspectiva contemporânea. In: Wittrock M. (ed.). La investigación en la enseñanza i: enfoques, teorías y métodos[Internet]. Madrid: Paidos-MEC; 1989[cited 2015 May 26]. p. 9-91. Available from: http://www.terras.edu.ar/biblioteca/11/11did_shulman_unidad_1.pdf.

18. Grossman PL, Wilson SMY, Shulman L. Profesores de sustancia: el conocimiento de la materia para la enseñanza. Profesorado [Internet]. 2005 [cited 2015 May 26];9(2):1-25. Available from: https://recyt.fecyt.es/index.php/profesorado/article/download/42833/24723.

19. Shulman L. Theory, practice, and the education of professionals. The elementary school journal [Internet]. 1998 [cited 2015 May 26];98(5):511-26. Available from: http://www.csun.edu/ ml727939/coursework/610/Shulman\%201998.pdf

20. Freire P. Política e educação. São Paulo: Paz e Terra; 2014.

21. Krieger D, Mendes AM, Backes VMS. Conhecimento Pedagógico do Conteúdo, uma reflexão da prática docente a partir da teoria de Lee S. Shulman. Rev UNIPLAC [Internet] 2018 [cited 2018 Aug 20];6(1). Available from: https://revista.uniplac.net/ojs/index.php/uniplac/article/view/3264

22. Backes VMS, Menegaz JC, Miranda FAC, Santos LMC, Cunha AP, Patrício SS. Lee Shulman: contribuições para a investigação da formação docente em enfermagem e saúde. Texto Contexto Enferm [Internet]. 2017[cited 2018 Aug 30];26(4):e1080017. Available from: http://dx.doi. org/10.1590/0104-07072017001080017

23. Marcelo C. Formación del profesorado para el cambio educativo. Barcelona: PPU; 1995.

24. Bolivar A. Conocimiento didáctico del contenido y didácticas específicas. pedagogical content knowledge and subject matter didactics. Profesorado [Internet]. 2005 [cited 2018 Aug 30];9(2):1-39. Available from: https://www.ugr.es/ recfpro/rev92ART6.pdf

25. Marcon D. Conhecimento pedagógico do conteúdo. A integração dos conhecimentos do professor para viabilizar a aprendizagem dos alunos. Caxias do Sul, RS: EDUCS; 2013. 
26. Tardif M. Saberes docentes e formação profissional. 13. ed. Petrópolis: Vozes; 2012.

27. Joanara RF, Prado ML, Lazzari DD, Jardim VLT. Nursing higher education in MERCOSUR: a bibliometric study. Rev Bras Enferm [Internet]. 2018 [cited 2018 Aug 13];71(Suppl 4):1732-9. Available from: http://dx.doi.org/10.1590/0034-7167-2017-0405

28. Michaelis: Dicionário de português online [Internet]. 2009[cited 2018 Aug 13]. Dom. Available from: http://michaelis.uol.com.br/moderno/ portugues/index.php?lingua=portugues-portugues \&palavra $=$ dom 